\title{
Infrastructure of Dust \\ Managing Particulate in the Borderland
}

\author{
ERSELA KRIPA \& STEPHEN MUELLER
}

Texas Tech University

\begin{abstract}
Airborne particulate in the US/Mexico border region indexes an emerging transnational security concern, enabling the proliferation of novel managerial infrastructures. Through an investigation of the weaponized atmospheres and securocratic frontiers of cross-border dust, the paper uncovers an invisible agent with the capacity to reshape bodies, buildings, cities, and territories in its image.
\end{abstract}

\section{DUST AS TRANSNATIONAL SECURITY CONCERN}

Dust surrounds us, saturating our atmosphere with a nearly imperceptible, but transcontinental airborne geology. Particulate matter disturbed from geologic strata, and the infinitesimal artifacts of anthropocenic intervention conspire to create an ever-present material ecology, suspended in our cities and streets, deposited in our homes. Microscopic bits of soil, sand, ash, and soot creep unnoticed through the everyday, vectors for the transmission of chemical, biological, and cultural materiel. The ability of dust to infiltrate boundaries, cross borders, and invade bodies has made it a primary security concern in the evolving transnational threat environment.

Dust, while often considered inert, is indeed a highly effective agent for transforming vast territories. The massive, intercontinental 'dust export' of the Saharan Desert that crosses the globe contributes to microbial growth and ice melt in Antarctica, sustains the health of ecosystems in the Amazon, and acts as the major life support system for the world's oceans, delivering vital trace elements like iron to nutrient-starved regions[1]. The dust-laden Saharan Air Layer $(\mathrm{SAL})$, leaving in bursts from Western Africa every three to five days throughout the summer months, is said to both contribute to devastating algal blooms in the Gulf of Mexico, and to play a key role in diminishing the gathering force of tropical Atlantic storms[2].

New dust and sand sources are regularly created, discovered and exploited through a combination of natural and anthropogenic agents[4]. With desertification accelerating in an era of rapid climate change, existing sources of transnational dust flow are being naturally extracted, their boundaries expanding. Adding to the natural erosion of sand and dust sources, human agents and growing pressures of urbanization are targeting and expanding dust sources for profit. Transnational criminal enterprises engage in sand smuggling[3] and other clandestine practices. This vast unregulated economy, dependent on the wholesale extraction of geologic material, is literally changing the map.

These vast migrations of dust carry with them a latent, but operative intelligence, clues to help us better understand our changing world. The first indications of shifting biospheres, emerging human and animal habitats, and criminal abuses are indeed encoded within the smallest of airborne particles. Geologists routinely investigate dust deposits, miles away from their source, searching for the unique

Figure 1: Aerosol Optical Depth [Showing Dust Export from Saharan Air Layer] - Adapted from NASA Earth Observatory (NEO) May 2016

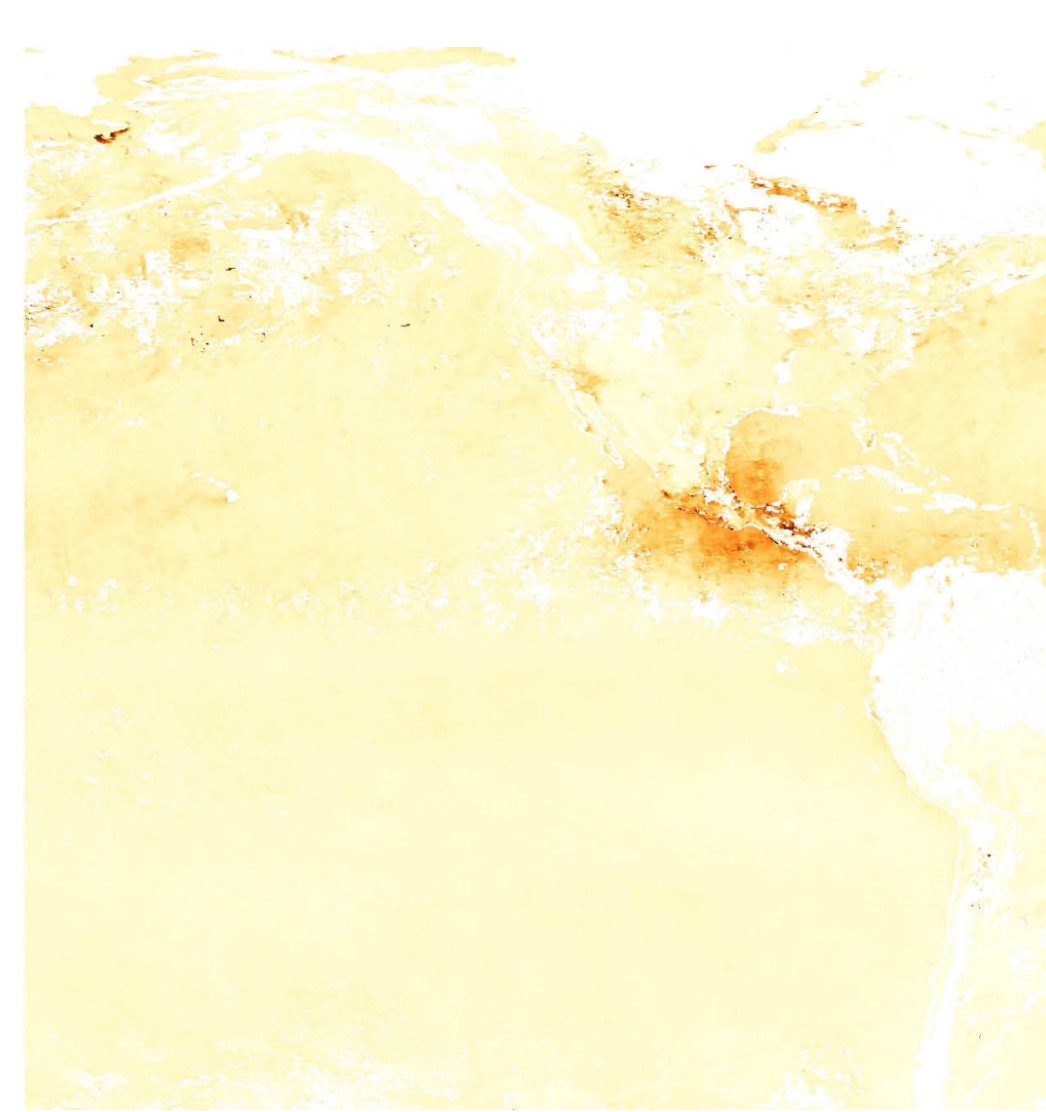


planetary particulate regime. Rusin and Flit show in their "upbeat" propagandist pamphlet, Man vs. Climate, several radical proposals for re-engineering the planet at the service of Soviet interests. Citing dust storms as a significant detriment to domestic security and a challenge to overcome in the projection of power abroad, the authors herald a brave new world of atmospheric control in the service of the Soviet state. Included in the pamphlet is a proposal by Gorodsky and Cherenkov which advocates for surrounding the Earth in a ring of dust, "similar to the ring around Saturn," in order to block the effects of solar radiation and limit the volatility of seasonal temperature differentials[10].

The US, meanwhile, was using theaters of operation as testing grounds for weather warfare. Operation POPEYE, an intensive, classified cloud-seeding operation bombarded Vietnamese airspace with lead and silver iodide in an attempt to extend the monsoon season and hinder supply chains. After the operation was made public, the US Senate and United Nations each passed resolutions against the use of such wartime environmental modification techniques[11], setting a precedent for a juridical autonomy of atmosphere predicated on the nation-state, coincident with national sovereignty but dependent on mutualist planetary regulation.

While a great deal of skepticism, along with ethical and scientific uncertainty surrounds such large-scale experiments, the scientific community is returning to proposals for geo-engineering with renewed vigor. Buoyed by a speculative report[12] from the US Department of Defense on the possible national security impacts of global warming for US military and strategic interests, techno-futurist scientific endeavor has shifted to investigate macro-engineering techniques which privilege an image of the planet increasingly subject to arid, windblown, dusty landscapes. The Pentagon's mandate to "explore geo-engineering options that control the climate" found an inspiration and ready recruit in the prevalent migrations of global dust.

A 2003 study advocated for stratospheric dust injections to combat the detrimental effects of ozone layer depletion in sensitive areas[13]. More recent, and more earnest proposals from geo-engineering specialists suggest new futures for dust, accelerating the effects of natural dust deposits and enlisting them in the battle for planetary atmospheric stability. Drawing on the historic ability of dust to fertilize the planet's nutrient-rich oceans and encourage algal blooms, one proposal from 2008 suggests targeted artificial fertilization. The resulting algal territories would, the authors suggest, act as a carbon sink and limit the effects of global warming[14].

Adapting to the UN mandate for a drawdown on weaponized atmospheres, the military has shifted its target from the weather itself to the sensors and systems which help an enemy to understand its impact and forecast its behavior. A recent proposal from the US Air Force for next-gen weaponized atmospheres suggests "clouds of microscopic computer particles that could block an enemy's optical sensors or guide smart weapons to their targets"[15].

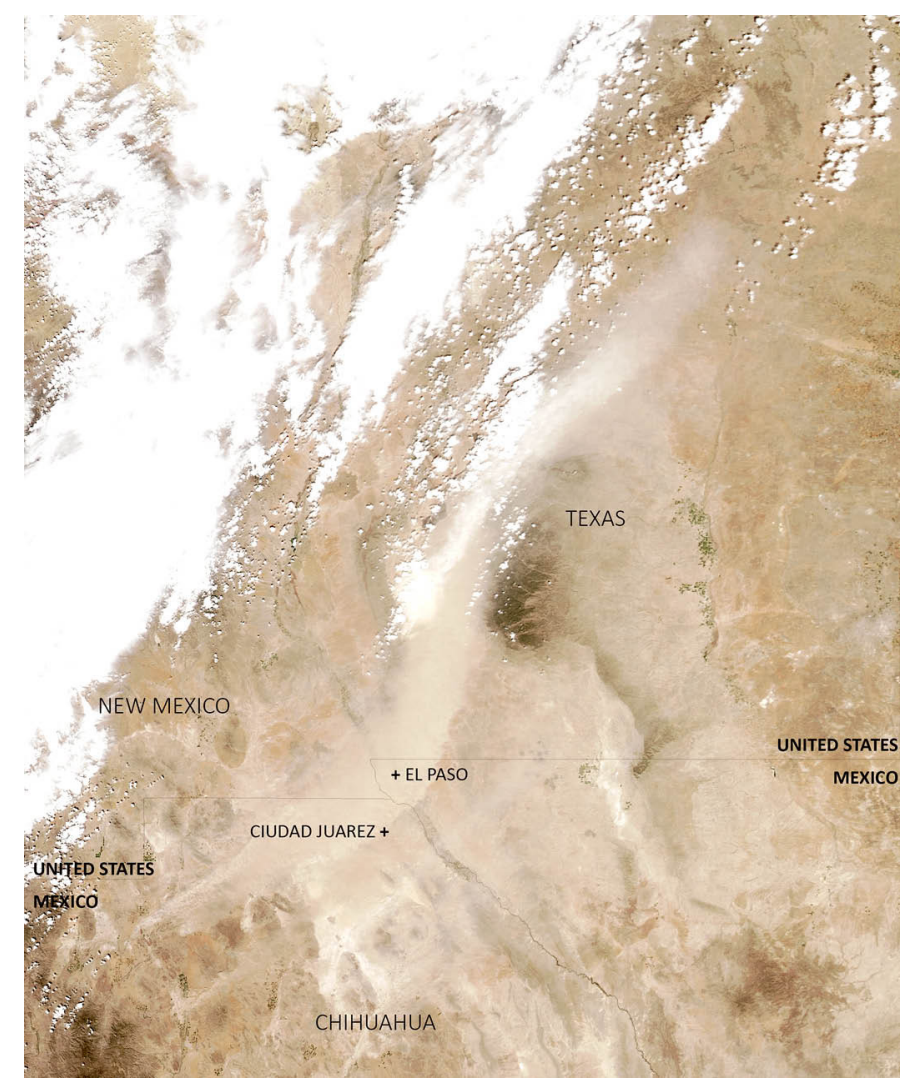

Figure 2: Transnational Dust Storm over El Paso / Ciudad Juarez -Adapted from NASA Earth Observatory April 2012

\section{SECUROCRATIC DUST FRONTIERS}

In parallel with this macro-scale research in weaponized atmospheres, military strategists have developed and appropriated physical, terrestrial territories to augment weaponized particulate experimentation. Trajectories for the possible impact of dust and other airborne particulate on global security are embedded in a series of securocratic territories, managerial militarized landscapes which deploy infrastructural technologies to privilege the reading of dust as contaminant, weapon, and threat. A series of landscape-scale and urban environment simulations speckled across the US domestic interior demonstrate an ongoing military commitment to the defense and tactical deployment of particulate management.

Dugway Proving Ground is host to one of the earliest such installations, dedicated from its creation in 1942 to managing the effects of weaponized airborne threats from chemical, biological, and nuclear material. The collection of simulated German and Japanese villages act as a kind of physical computer for airborne particulate, an urban laboratory for testing response and attack. The site itself required extensive particulate management strategies to maintain the integrity of the future experiments, creating a kind of neutral atmosphere and control scenario against which future atmospheric incursions could be measured. The first order of business was to control the amount of blowing sand on site by importing massive amounts of gravel, setting the stage for future experiments[16], creating the control condition against which future airborne incursions could be measured. 
Also in Utah, the Deseret Test Center at Fort Douglas used chemical and biological simulants to test region-scale affects of airborne contaminants, leading to the long-term modification of neighboring landscapes and ecosystems, adversely affecting public and animal health. This feedback between a designed, controlled, and localized intervention and its unpredictable territorial reach would be a consistent feature and design problem for particulate simulation facilities to overcome.

While purpose-built constructions like those at Dugway are valuable in simulating complex interactions of built form and airborne particulate, the military also appropriates existing urban forms and infrastructures to conduct its tests. Beginning in 1953, the US Army Chemical Corps staged mock chemical attacks on real cities, including St. Louis, Minneapolis, and Winnipeg[17]. The Large Area Concept experiments, begun in 1957, extended this experimental territory, requiring the complicit coordination of multiple jurisdictions. The experiments included analyses of downwind effects across multiple states, infusing the atmosphere with simulants which allow researchers to trace the range of the foreign agent.

The simulants used in such tests, which themselves pose a range of threats, still line these urban landscapes and trans-jurisdictional domestic territories. In St. Louis, predominantly African American neighborhoods, replete with high-density modernist public housing complexes, were chosen for similar tests based on their resemblance to the Soviet urban fabric then a primary target for operations. This insidious history of particulate contamination has only recently been revealed with renewed government interest in the redevelopment of the ill-fated Pruitt-Igoe site. Environmental assessments support speculation that chemical contaminants and radioactive tracers may have been deployed[18].

Recognizing that transmission of particulate occurs not only within the fabric but through the systems of the city, the infrastructural spaces of the city are recast as future sites of invisible airborne assaults as well. US Senator Orrin Hatch has reportedly advocated for the construction of a dedicated particulate testing facility, including a mock subway system, drawing on the complex and contested legacies of Utah's simulated urban landscapes[19]. More recent experiments managed by the Department of Homeland Security have used the New York subway system itself as a ready-made test site, speculating on the use of the passing trains as efficient aerosol dispersal mechanisms and testing their assumptions in real time. Unsuspecting commuters contribute to the reality of the simulation[20]. Similar studies used transit infrastructures in Boston and Washington, D.C. in recent years.

Back at Dugway, a new securocratic frontier is being sketched. Test facilities once dedicated to military use are now used in a 'global challenge', open to foreign agencies and private companies to test their defenses against airborne chemical or biological simulants. Point detectors can register presence of agents on site, while standoff detectors use lasers to detect agents at a distance. The Active Standoff Chamber and Ambient Breeze Tunnel provide two different environments for response teams to test their tech within controlled airflow environments. Tests can be expanded to an outdoor "massive test grid" which allows for natural airflow to affect the simulant[21]. Operators of the facility provide only the infrastructure, and do not themselves collect any data on the capabilities, technologies, experiments, or readings of the 'customers' allowed to test. This confirms a trend, documented in the 'Copies of Copies: Simulated Cities From Security to Logistics' essay by Ersela Kripa in this issue, where military training facilities are increasingly sharing space and resources with the private sector. Competing national security systems for the dispersal, collection, and detection strategies of airborne contaminants briefly and democratically inhabit this neutral test zone in the name of scientific advancement, only later to be deployed for geopolitical and military advantage.

Figure 3: Haboob, Ransom Canyon Texas - Wikimedia User Leaflet, Creative Commons

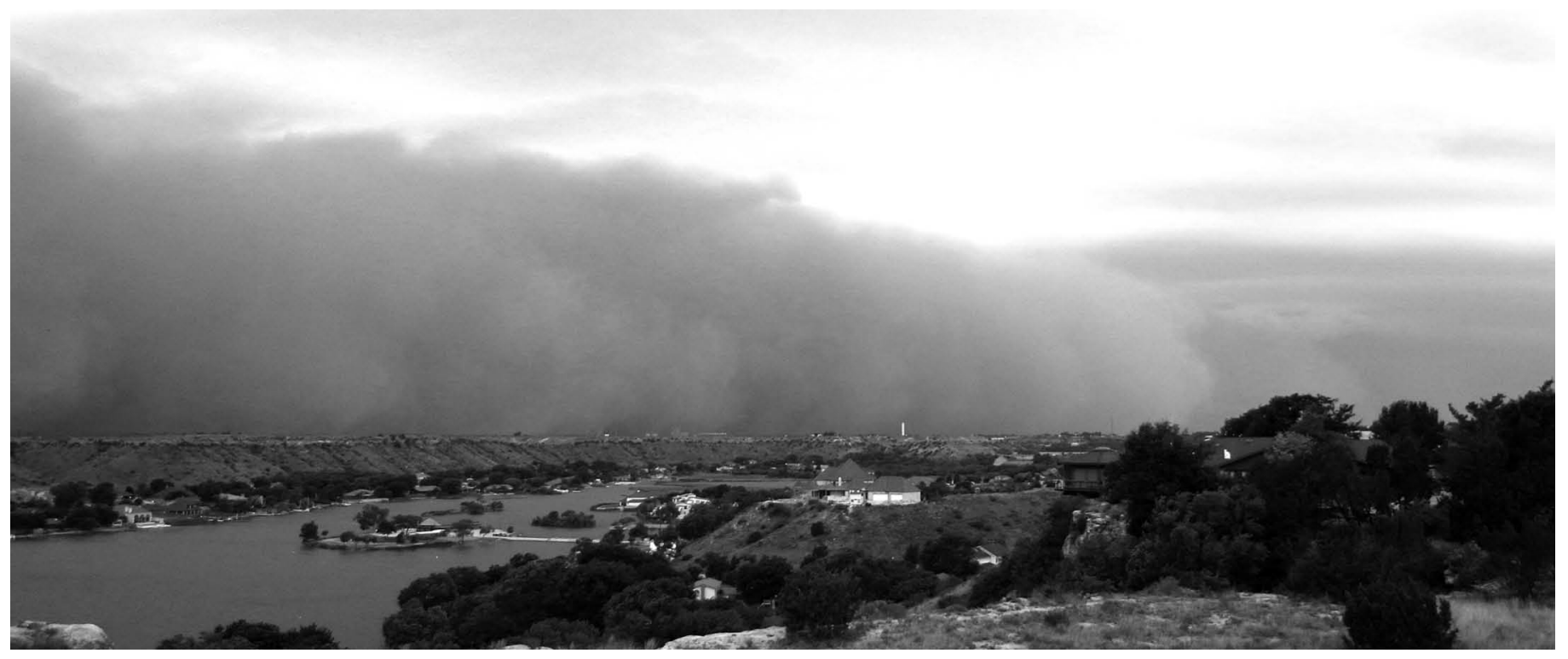




\section{FOREIGN SOIL}

With the increased technological ability to monitor airborne contamination across juridical and sovereign boundaries, dust has become a suspect transnational and potentially criminal entity, and vector for geopolitical strategy. In practice, US border regulators are giving new credence to the term foreign soil.

Security agencies are increasingly concerned with foreign particle contaminants within the domestic interior, including the unintentional transmission of foreign biogenetic material through soil-borne organisms, and risks from agro-terrorism - the intentional introduction of harmful foreign materials to a nation's agriculture or food supply[22].

Federal regulators thus consider the interstate transmission of soil to be an "extremely high risk activity," requiring special permits for imported soil, especially when deliberately transmitted in large quantities[23]. The buildup of foreign soil and windblown dust on farm equipment, in shipping containers and vehicles, as well as military materiel demands immediate response[24]. While some material, like low quantities of decorative beach sand - so-called pure sand-does not constitute a significant threat, other sources are subject to more intense scrutiny, necessitating heat and pressure sterilization procedures at designated ports of entry[25]. NAFTA provisions require extensive verifications to ensure an accountable origin and travel path for goods shipped under the agreement. These specifically allow for dust accumulated during shipment to be removed as part of normal operations.

With domestic agriculture seen as a vast economic engine and 'soft' target post-9/11, security efforts to detect and respond to airborne contaminants have increased. While there have been only twelve

Figure 4: Spring Dust Storm, El Paso [Franklin Mountains Not Visible in Background] - Hadley Paul Garland, Creative Commons documented cases of agro-terrorism in the past century[26], and none involving the use of aerosol dispersants targeting soil composition, investigators speculate on the terrorist use of chemical contaminants and poisons like ricin in such scenarios[27]. Dust generators and dust fraction collector assemblies are used to gauge the transfer of dust from contaminated sites through wind, human, and machinic vectors[28]. These studies anticipate future acts of agroterrorism, which can include the introduction of chemical irritants through the aerosol dispersal mechanisms of highly modified crop dusters[29] and the spreading of low levels of radioactive materials in agricultural soil. Despite these attempts to maintain the integrity of domestic soil, dust migrates and transgresses these boundaries constantly.

\section{CHIHUAHUA DESERT AS SITUATED CREATIVE MACHINE}

Within this context, the El Paso/Ciudad Juárez border metroplex can be seen as a particularly vital situated creative machine. The binational metropolis, while separated by national security infrastructures, is joined by the geologic and climatological anomalies of the stark and rapidly changing Chihuahuan Desert.

The desert defines a transnational territory with unique geomorphological characteristics and a vocabulary all its own. Dry lake beds - or playas - throughout the desert funnel dust indiscriminately across the international boundary. The dust forges a new territory of shared particulates - ingested by buildings, landscapes, machinery, and citizens alike. Dust devils, haboobs, and dust storms reshape the experience of the city and landform. Microbursts, and dust plumes appear locally as ephemeral manifestations of a shifting landscape. These all reduce visibility and cause threats to human health, safety, and life.

El Paso and Ciudad Juárez together form a critical node in the regional geology of dust. Recurring dust events sweep through the region on a

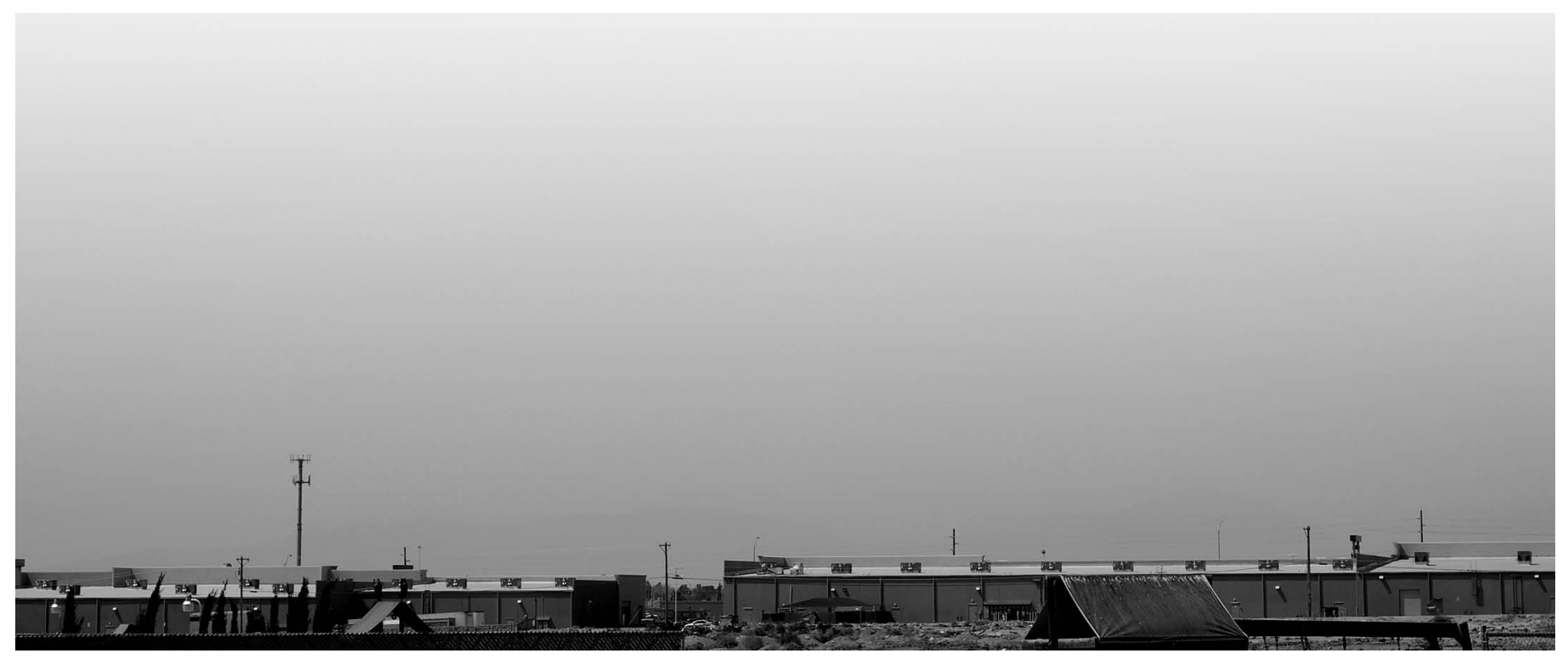




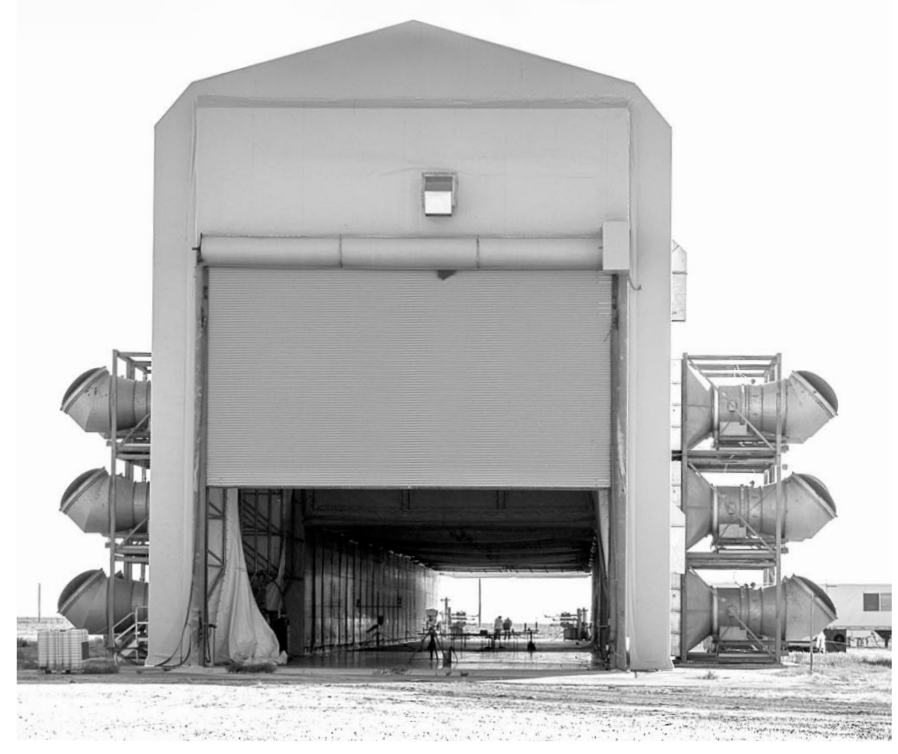

Figure 3: Joint Ambient Breeze Tunnel, Dugway - US Army / Public Domain

seasonal basis, enacting shared infrastructures of security, control and response. A distributed dust infrastructure is growing, including a constellation of monitoring stations, desert research facilities, broadcast sites, and emergency response facilities. At the scale of the binational region, air quality monitoring stations are stationed to measure airborne particulate and serve as early indicators of impending events. Water trucks are mobilized to construction sites to weigh the dust with moisture, inhibiting travel of so-called fugitive dust [30]. Track-out control devices on work sites ensure dust is not carried away by machinery, vehicles or other equipment, each granule either deposited close to site of origin or forced off the machines with pressurized water.

Other examples of soft dust infrastructure emerge to capture and control the spread. Regular customs and border screenings are conducted to inhibit the free travel of pathogens, biological or agricultural material either purposefully or accidentally concealed, grafted within the network of logistics infrastructure-rail cars, shipping containers, and tractor trailers. Sweeps for dust can involve high tech sensing equipment and sensitive microscope or low-tech solutions, including customs agents with sturdy brooms.

The dust provides both cover and a signal for illicit activity. Dust trails from moving vehicles in the desert landscape routinely map the workings of narcotraffickers, accelerating the work of Customs and Border Patrol (CBP) agents. Recently agents in Nogales, AZ were led by a dust trail to an abandoned truck near the border, where more than 1,000 pounds of marijuana[31] were discovered unattended. A similar incident led agents in McAllen, TX to another 1,027 pound seizure, this time from an abandoned Chevy Tahoe[32].

The technologies of dust storm detection and human detection collapse on the border, with sequential imaging, infrared technologies, and radar common tools for both. In one instance the CBP newsroom applauds the agents' use of infrared technology to continue drug seizures despite significant dust storms [33]. The new VADER imaging technology deployed by the CBP began as a mobile vehicle-mounted radar and is now installed in overhead drones to produce overhead imagery. VADER is celebrated for its ability to locate undocumented migrants through the visual fog of dust storms and atmospheric haze[34], extending the gaze of the security state. Mobile radar units are similarly deployed in the civilian sector in order to observe bodies and movements which are unintelligible to stationary observers, improving haboob prediction algorithms[35].

These types of negotiations between sensing infrastructures and dusty landscape leads to a kind of infrastructural arms race over the control and manipulation of the cross border geology. Traffickers exploit geologic contingencies to locate cross border smuggling tunnels in easy-to-dig, but easy-to-retain areas of sandy soil, building them quickly and without additional reinforcement. These areas also happen to make it very difficult for tunnels to be discovered, as advanced electromagnetic imaging sees the geology, tunnel and water table equally as 'noise' [36]. Security forces and traffickers both adapt their vehicles to the dusty terrain, deploying All-Terrain Vehicles (ATVs) -also called dune buggies or sand rails - to navigate the desert terrain. Narcotraffickers use the sand to bury their stash[37].

The atmospheric effects of cross-border dust have also inhibited operations and endangered lives. Dust has been cited as a factor in agent deaths during vehicle chases on dusty roads [38]. Human traffickers have used shipments of sand to conceal their clandestine cargo, which on delivery has forced aliens to be nearly suffocated and 'cough up sand'[39].

The forensic attitude of dust control agents is not only passively measuring but also actively affecting the territory. Geoscientists deploy tracers, chemical compounds and identifiable isotopes distributed across an origin landscape to act as transmitted chemical signatures[40], making the origin site identifiable when the dust transmission is complete. Recent advances in aerosol tracking technologies seek to minimize the impact of this airborne micro-geology as it enters and leaves the bodies it inevitably encounters. A proprietary system named DNATrax embeds a unique artificial DNA signature within inert aerosol sugars, a particulate barcode which ties the particle back to its place of origin.

Transnational dust can be seen as a primary vector, an abstract machine, which connects and organizes disparate political economies, transmits cultural and geologic material across different regimes of urban inhabitation, and acts as an engine for geopolitical engineering from the technologic to the planetary scale.

\section{ENDNOTES}

1. Radford, Tim. “Desert Dust Feeds Deep Ocean Life." Scientific American. 16 Jul 2014 http://www.scientificamerican.com/article/desert-dust-feeds-deep-ocean-life/

2. Dolce, Chris and Jon Erdman. "Saharan Dust From Africa Brings Hazy Skies to Texas Gulf Coast." 13 Jul 2016. The Weather Channel. https://weather.com/science/weather-explainers/news/ saharan-air-layer-african-dust-atlantic-basin?_escaped_fragment_ 
3. Milton, Chris. "The Sand Smugglers." 4 Aug 2010. Foreign Policy. http://foreignpolicy.com/2010/08/04/the-sand-smugglers/

4. NASA Visible Earth. "Dust Marches Across Iraq and Iran." 3 Sep 2015. http:// earthobservatory.nasa.gov/NaturalHazards/view.php?id=86539\&eocn=image\&eoci =morenh

5. See Eyal and Ines Weizman. Before and After: Documenting the Architecture of Disaster. Strelka Press, 2016.

6. McBride, Earl. "Shrapnel in Omaha Beach Sand." Sedimentary Record Vol.9 No. 3. SEPM: Sep 2011. https://www.sepm.org/CM_Files/SedimentaryRecord/ SedRecord\%209-3.pdf. [See also Geoff Manaugh "War Sand." BLDGBLOG. 11 Aug 2012 http://www.bldgblog.com/2012/08/war-sand/]

7. UNEP. "Global Assessment of Sand and Dust Storms - Draft Report." http://uneplive. unep.org/media/docs/assessments/global_assessment_of_sand_and_dust_ storms.pdf

8. Bautista, Francisco. "The Magnetic Increase in Urban Dust as an Indicator of Environmental Pollution." SKIU. 30 Nov 2015. http://www.actswithscience.com/ the-magnetic-increase-in-urban-dust-as-an-indicator-of-environmental-contamination/

9. Fleming, James Rodger. "The Pathological History of Weather and Climate Modification: Three Cycles of Promise and Hype." Historical Studies in the Physical and Biological Sciences, Vol. 37, Number 1. 2006. http://www.colby.edu/sts/06_ fleming_pathological.pdf

10. Schneider, Stephen H. "Geoengineering : Could We or Should We Make It Work?" Philosophical Transactions of the Royal Society. Aug 2008. http://rsta.royalsocietypublishing.org/content/roypta/366/1882/3843.full.pdf?origin=publication_detail

11. Fleming.

12. Schwartz, Peter and Doug Randall. "An Abrupt Climate Change Scenario and Its Implications for United States National Security." Accessed online at http://stephenschneider.stanford.edu/Publications/PDF_Papers/SchwartzRandall2004.pdf

13. Schneider

14. Smetacek, V and S.W.A $>$ Naqvi. "The Next Generation of Iron Fertilization Experiments in the Southern Ocean." Philosophical Transactions of the Royal Society. 13 Nov 2008. http://rsta.royalsocietypublishing.org/ content/366/1882/3947

15. Fleming.

16. Ison, Vyvette D. "Chemical Weapons Testing Creates Controversy at Dugway." History Blazer. Jul 1995.https://heritage.utah.gov/history/ uhg-chemical-weapons-testing

17. Salter, Jim. "The Army Sprayed St. Louis With Toxic Aerosol During a Just Revealed 1950s Test." Business Insider. 4 Oct 2012. http://www.businessinsider.com/ army-sprayed-st-louis-with-toxic-dust-2012-10?IR=T

18. Salter.

19. Deseret News. "The Fight Against Terrorism." http://m.deseretnews.com/article/627779/The-fight-against-terrorism.html?pg=all. [See also Bratton, Benjamin $\mathrm{H}$. Dispute Plan to Prevent Future Luxury Constitution. 7 Jan 2016. Sternberg Press.]

20. Associated Press. "Harmless Gas Released Into New York Subway to Prep for Biological Attack." The Guardian. 9 May 2016. https://www.theguardian.com/us-news/2016/may/09/ new-york-city-subway-harmless-gas-released-biological--attack-study-jessica-now

21. Vogel, Al. “Dugway to Challenge Global Chem/Bio Tech.” US Army. 29 Jun 2016. https://www.army.mil/article/170713/dugway_to_challenge_global_chembio_tech

22. US Customs and Border Protection. "Protecting Agriculture." https://www.cbp.gov/ border-security/protecting-agriculture

23. US Department of Agriculture. "Soil Permit Process." 19 May 2015. https:// www.aphis.usda.gov/aphis/ourfocus/planthealth/import-information/permits/ regulated-organism-and-soil-permits/SA_Soil/CT_Soil_permit_process

24. US Customs and Border Protection. "Carrier Conveyance Contamination." Aug 2014. https://www.cbp.gov/sites/default/files/documents/Web\%20Based\%20Version\%20 Carrier\%20Conveyance\%20Contaminant\%20Trade\%200utreach_August\%20 2014_final\%20-\%20Copy3.pdf
25. US Department of Agriculture. "Soil Treatment Facilities." https://www. aphis.usda.gov/aphis/ourfocus/planthealth/import-information/permits/ regulated-organism-and-soil-permits/sa_soil/ct_soil_under3pounds

26. Olson, Dean. "Agroterrorism: Threats to America's Economy and Food Supply." Federal Bureau of Investigation (FBI). Feb 2012. https://leb.fbi.gov/2012/february/ agroterrorism-threats-to-americas-economy-and-food-supply

27. Linacre, Nicholas A.; Koo, Bonwoo; Rosegrant, Mark W.; Msangi, Siwa; Falck-Zepeda, Jose' Benjamin; Gaskell, Joanne; Komen, John; Cohen, Marc J. and Birner, Regina. 2005. "Security analysis for agroterrorism: applying the threat, vulnerability, consequence framework to developing countries." EPTD Discussion Paper 138. Washington, D.C.: International Food Policy Research Institute (IFPRI). http://ebrary. ifpri.org/cdm/ref/collection/p15738coll2/id/69083

28. Kendall, Ronald J, Steven M. Presley and Seshadri S. Ramkumar. New Developments in Biological and Chemical Terrorism Countermeasures. CRC Press. 17 Feb 2016.

29. Hodges, Amanda and Rick Sapp. "The Threat of Agroterrorism and Bioterrorism in Florida - Prevention and a Coordinated Response." Florida Department of Agriculture and Consumer Services. Oct 2006. http://www.flsart.org/pdf/ Lesson\%20Plan\%20Part\%201.pdf

30. New Mexico Environment Department Air Quality Bureau. "Fugitive Dust Control Techniques and Businesses." https://www.env.nm.gov/aqb/dust_control2.html

31. US Customs and Border Protection. "Border Patrol Checkpoints Prove Vital to Weekend Seizures." 28 Jun 2010. https://www. cbp.gov/newsroom/local-media-release/2010-06-28-040000/ border-patrol-checkpoints-prove-vital-weekend

32. Ibid.

33. US Customs and Border Protection. "Despite Dust Storms Border Patrol Agents Continue Seizing Narcotics." 11 Apr 2013. https:// www.cbp.gov/newsroom/local-media-release/2013-04-11-040000/ despite-dust-storms-border-patrol-agents-continue

34. Becker, Andrew. "New Drone Radar Reveals Border Patrol 'Gotaways' in High Numbers." The Center for Investigative Reporting. 4 Apr 2013. http://cironline.org/ reports/new-drone-radar-reveals-border-patrol-gotaways-high-numbers-4344

35. The National Severe Storms Laboratory. "Research Tools : Mobile Radar." http:// www.nssl.noaa.gov/tools/radar/mobile/

36. Reel, Monte. "Underworld: How the Sinoloa Drug Cartel Digs Its Tunnels." The New Yorker. 3 Aug 2015. http://www.newyorker.com/magazine/2015/08/03/ underworld-monte-reel

37. US Customs and Border Protection. "Border Patrol Agents Uncover Marijuana in Arizona Sand Dunes." 16 Feb 2010. https://www. cbp.gov/newsroom/local-media-release/2010-02-16-050000/ border-patrol-agents-uncover-marijuana-arizona-sand

38. US Customs and Border Protection. "Border Patrol Checkpoints Prove Vital to Weekend Seizures."

39. US Customs and Border Protection. "CBP Arrests Two Illegal Aliens Hidden in a Dump Truck Full of Sand." 18 Nov 2010. https://www. cbp.gov/newsroom/local-media-release/2010-11-18-050000/ cbp-arrests-two-illegal-aliens-hidden-dump-truck-full

40. Etyemezian, Vic et al. "Dust Impacts on the Twenty Percent Worst Visibility Days." http://slideplayer.com/slide/4778068/ 